\title{
DISTRIBUTION AND CONSERVATION STATUS OF THE CAUCASIAN PARSLEY FROG, PELODYTES CAUCASICUS (AMPHIBIA: ANURA)
}

\author{
Spartak N. Litvinchuk ${ }^{1}$, Artem A. Kidov ${ }^{2}$ \\ ${ }^{1}$ Institute of Cytology of RAS, Russia \\ e-mail: litvinchukspartak@yandex.ru \\ ${ }^{2}$ Russian State Agrarian University - K.A. Timiryazev Moscow Agricultural Academy, Russia
}

Received: 13.03 .2018

\begin{abstract}
Pelodytes caucasicus inhabits Turkey, Georgia, Abkhazia, South Ossetia, Azerbaijan, and six regions of Russia (226 localities). The forest cutting strongly threatens its populations. Therefore, the frog is listed in Red Data Books of Georgia, South Ossetia, Azerbaijan, and the Russian Federation. Additional factors influencing the decline of $P$. caucasicus populations are destruction and contamination of suitable water bodies, clearing of forests from fallen trees, destroying of litter, mortality on roads, and preying by the introduced North American raccoon. Using of MaxEnt, we developed a species distribution model based on climate, landscape and land cover data to estimate the potential distribution range, ecological preferences and conservation status of $P$. caucasicus. Two precipitation parameters, annual precipitation and precipitation seasonality, had the highest contribution percentage to the model ( $52 \%$ and $11 \%$ respectively). As a rule, suitable habitats for the species located in woodland mountain areas with annual precipitation ranged from $513 \mathrm{~mm}$ to $2376 \mathrm{~mm}$. Drier regions to the north and south of the Caucasus limit its distribution.
\end{abstract}

Key words: Caucasus, GIS modelling, MaxEnt, Pelodytidae

\section{Introduction}

The Caucasian parsley frog, Pelodytes caucasicus Boulenger, 1896 (Fig. 1), is an endemic species of the Caucasian Isthmus, the region (about 580000 $\mathrm{km}^{2}$ ) delimiting Europe and Asia, and lying between the Black Sea in the west and the Caspian Sea in the east. The frog inhabits Turkey, Georgia, Abkhazia, South Ossetia, Azerbaijan, and Russia. On the territory of Russia, the species was found in six regions, namely in the autonomous republics of Adygea, Karachay-Cherkessia, Kabardino-Balkaria, North Ossetia-Alania, Chechnya, and Krasnodarsky Krai (Kuzmin, 2013). The occurrence of the species was assumed in the Dagestan Republic of Russia (Askenderov, 2017). Pelodytes caucasicus was listed as near-threatened by the IUCN (Kaya et al., 2009) and was included in the Appendix II of the Bern Convention, Red Data Books of Russia, Georgia, South Ossetia, Azerbaijan, the republics of Adygea, Karachay-Cherkessia, Kabardino-Balkaria, North Ossetia-Alania, Chechnya, and Krasnodarsky Krai of Russia (Kacharava, 1982; Udovkin \& Lipkovich, 1999; Dzuev \& Ivanov, 2000; Kuzmin, 2000; Lotiev, 2007; Tuniyev \& Tuniyev, 2012, 2017; Doronin, 2013; Lotiev \& Tuniyev, 2017).

The distribution of Pelodytes caucasicus is similar to other Caucasian forest amphibian species, which may suggest similar ecological requirements. However, the position of range boundaries for all these species is somewhat different. For example, the range of Mertensiella caucasica (Waga, 1876) in the Minor and Turkish Caucasus is basically coinciding with the distribution of $P$. caucasicus. However, the first species is absent in the Great Caucasus (Tarkhnishvili et al., 2008; Gül et al., 2018). Ommatotriton ophryticus (Berthold, 1846) occurs in North Armenia, but does not penetrate in Azerbaijan and the central part of the North Caucasus (Litvinchuk, 2017; Van Riemsdijk et al., 2017). Lissotriton lantzi (Wolterstorff, 1914) inhabits the Dagestan Republic of Russia, Armenia and the Lenkoran Lowland in Azerbaijan, but is lacking in the Black Sea coastal part of Turkey (Skorinov et al., 2014). Triturus karelinii (Strauch, 1870) occurs in the Dagestan Republic of Russia, the Crimea, Azerbaijan, Iran, but is absent in the Black Sea coastal part of Turkey (Litvinchuk \& Borkin, 2009; Wielstra et al., 2013a,b). The Caucasian part of ranges of Bufo verrucosissimus (Pallas, 1814) and Pelodytes caucasicus are approximately the same. However, the first species probably inhabits western and southern Turkey, eastern Bulgaria, Lebanon and Syria (Litvinchuk et al., 2008; Garcia-Porta et al., 2012; Arntzen et al., 2013; our data). The Caucasian lineage of Hyla orientalis Bedriaga, 1890 (Dufresnes et al., 2016), which could be recognised as a separate subspecies, is also associated with the Caucasian forest belt. However, unlike $P$. caucasicus it is widely distributed in the eastern part of the Caucasus and is lacking in the Black Sea coastal part of Turkey. 


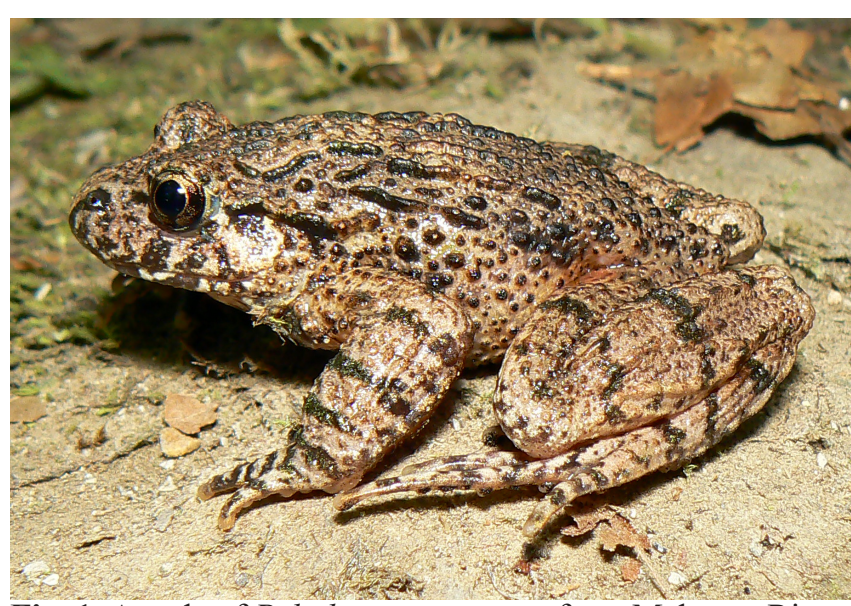

Fig. 1. A male of Pelodytes caucasicus from Makopse River, Krasnodarsky Krai, Russia.

The GIS-based ecological niche modelling is a rapidly developing area of research. Recently, numerous studies were made by using this method (Tarkhnishvili et al., 2008; Garcia-Porta et al., 2012; Dufresnes et al., 2016). The obtained models of species distribution could be useful for study of many aspects of ecology and conservation, predicting of new localities for rare and threatened species, and invasive species spread (Bombi et al., 2009; Lyet et al., 2013; Vences et al., 2017). This approach appears a good and reliable tool for past and future climatic scenario studies, too (Brito et al., 2011; Tarkhnishvili et al., 2012; Litvinchuk et al., 2013; Duan et al., 2016; Iannella et al., 2017; Wetterings \& Vetter, 2018). Therefore, the aim of this study was to apply the ecological niche modelling to predict potential distribution range, estimate ecological preferences and conservation status of Pelodytes caucasicus.

\section{Material and Methods}

To predict the potential distribution of the Caucasian parsley frog, we modelled the species distribution using MaxEnt (ver. 3.3.3k; Phillips et al., 2006). This algorithm combines environmental parameters with geographic co-ordinates and produces highquality predictions of species distribution, often more reliable when evaluated and compared with other predictive models (Hernandez et al., 2006). For the contemporary niche predictions, we used 226 localities, comprising own and previously published records (Tosonoğlu \& Taskavak, 2004; Zinenko \& Goncharenko, 2009; Iğci et al., 2013; Kuzmin, 2013; Gül, 2014; Tuniyev et al., 2017; Tuniyev, 2018). To avoid spatial autocorrelation of occurrence points, we filter them by ENMTools 1.3 (Warren et al., 2010).

The altitude and 19 bioclimatic layers representing climatic data for the past fifty years $(\sim 1950$ 2000) were extracted from the WorldClim 1.4 data- base (http://www.worldclim.org). Further, four layers (the aridity index, land cover, spatial homogeneity of global habitat, and global percent of tree coverage) were obtained from the following databases: Global Aridity and Potential Evapo-Transpiration (http://www.cgiar-csi.org/data/global-aridity-andpet-database), GlobCover 2009 (Global Land Cover Map; due.esrin.esa.int/globcover/), EarthEnv (http:// www.earthenv.org/texture.html), and Github (https:// github.com/globalmaps/gm_ve_v1) respectively. To consider topography in the model, four landscape layers (aspect, exposition, slope, and terrain roughness index) were calculated with QGIS (http://www. qgis.org/). We applied a mask that extends from $39^{\circ} \mathrm{N}$ to $46^{\circ} \mathrm{N}$ and $35^{\circ} \mathrm{E}$ to $50^{\circ} \mathrm{E}$. All analyses were conducted in the WGS 84 projection.

To eliminate predictor collinearity prior to generating the model, we calculated Pearsons's correlation coefficients for all pairs of bioclimatic variables using ENMTools. We excluded the variable of a correlated pair with $|r|>0.7$ that we considered to be the less biologically important of the two based on known preferences of Pelodytes caucasicus (Tarkhnishvili \& Gokhelashvili, 1999; Franzen, 2012; our data). The resulting dataset contained nine bioclimatic variables: Bio2 (mean diurnal range; ${ }^{\circ} \mathrm{C} \times 10$ ), Bio3 (isothermality; \%), Bio5 (maximum temperature of warmest month; ${ }^{\circ} \mathrm{C} \times 10$ ), Bio6 (minimum temperature of coldest month; ${ }^{\circ} \mathrm{C} \times 10$ ), Bio7 (temperature annual range; ${ }^{\circ} \mathrm{C} \times 10$ ), Bio8 (mean temperature of wettest quarter; ${ }^{\circ} \mathrm{C} \times 10$ ), Bio9 (mean temperature of driest quarter; ${ }^{\circ} \mathrm{C} \times 10$ ), Bio 12 (annual precipitation; $\mathrm{mm}$ ), and Bio15 (precipitation seasonality; CV).

We used layers with 30 arc seconds spatial resolution because Pelodytes caucasicus inhabits very heterogeneous mountain landscapes. Searching for new localities and for verification of previously published records, we visited Abkhazia, Georgia, South Ossetia, as well as Krasnodarsky Krai, KarachayCherkessia, Kabardino-Balkaria, North Ossetia-Alania, and Adygea republics of Russia in 2006-2014. Co-ordinates and altitude for previously published records (if they were not specified) were determined by use of Google Earth, taking into account known ecological preferences of the species.

A total of 18 variables were used (Table). Model performance was measured using the Area Under the Curve (AUC) derived from the Receiver Operating Characteristic (ROC) plots. AUC values range from 0.5 to 1.0 , with 0.5 indicating no greater fit than expected by chance and 1.0 indicating a perfect model fit. AUC values above 0.75 are considered useful and above 0.90 very good (Swets, 1988; Elith, 2002). To 
properly parameterise the model, we evaluated the performance of various combinations of ten regularisation multipliers (from 0.5 to 5.0, in increments of 0.5; see details in Vences et al., 2017). The best-fit model was parameterised with a regularisation multiplier of 1.0 (30 replicates). We used default settings in MaxEnt, i.e. all feature classes, maximum iterations 500 and maximum number of background points 10000 (Phillips \& Dudík, 2008). We applied a jackknife analysis for estimating the relative contributions of variables to the MaxEnt model.

Table. Results of jackknife analysis for estimation of relative contribution of variables to the MaxEnt model

\begin{tabular}{lc}
\hline Variable & $\begin{array}{c}\text { Percent of } \\
\text { contribution }\end{array}$ \\
\hline Annual precipitation (Bio 12) & 51.9 \\
Precipitation seasonality (Bio 15) & 11.2 \\
Aridity index & 9.1 \\
Terrain roughness index & 8.0 \\
Altitude & 5.8 \\
Slope & 3.8 \\
Temperature annual range (Bio 7) & 1.7 \\
Mean diurnal range (Bio 2) & 1.4 \\
Isothermality (Bio 3) & 1.3 \\
Habitat homogenity & 1.2 \\
Mean temperature of wettest quarter (Bio 8) & 1.1 \\
Tree coverage percent & 1.1 \\
Land cover & 1.1 \\
Maximum temperature of warmest month (Bio 5) & 0.6 \\
Mean temperature of driest quarter (Bio 9) & 0.4 \\
Minimum temperature of coldest month (Bio 6) & 0.2 \\
Aspect & 0.1 \\
Exposition & 0.0 \\
\hline & \\
\hline
\end{tabular}

\section{Results}

All defined records of Pelodytes caucasicus have been summarised in Fig. 2 and the Appendix. About half of the localities $(n=108)$ were found in the North Caucasus (Russia), where a majority was revealed in its westernmost part (98 localities in Krasnodarsky Krai and Adygea). In the eastern part of the North Caucasus, records of the species were single (10). In Transcaucasia, localities of $P$. caucasicus were numerous in Georgia (56), northeastern Turkey (25), Abkhazia (21), and South Ossetia (12 localities). Records of the species in northwestern Azerbaijan were few (4).

The MaxEnt model for Pelodytes caucasicus had robust evaluation metrics. The average test AUC for the replicate runs was evaluated as 0.939 and the standard deviation was 0.031 . The predicted potential distribution is shown in Fig. 3. Estimates of relative contributions of variables to the species are shown in the Table. Of the parameters included in the model, annual precipitation and precipitation seasonality were variables with the highest percentage contributions ( $52 \%$ and $11 \%$ respectively). Other parameters had no notable contribution (less than 10\%). Suitable habitats for the species were located in areas with annual precipitation ranging from $513 \mathrm{~mm}$ in several localities in Turkey to $2376 \mathrm{~mm}$ in Batumi botanical garden in Georgia (mean $1068.7 \mathrm{~mm}$; $\mathrm{SD}=313.3$; Fig. 4). As a rule, the species was revealed in mountain areas with an altitude ranging from sea level to about $2300 \mathrm{~m}$ a.s.l. in Tskhra-Tskharo Pass in Georgia (mean 842.3; SD = 588.9; Fig. 4), only occasionally penetrating to adjacent plains in the North Caucasus (Goryachiy Klyuch) and the Colchis lowland (Kulevi and Poti). Drier regions to the north and south of the Caucasus limit the species distribution.

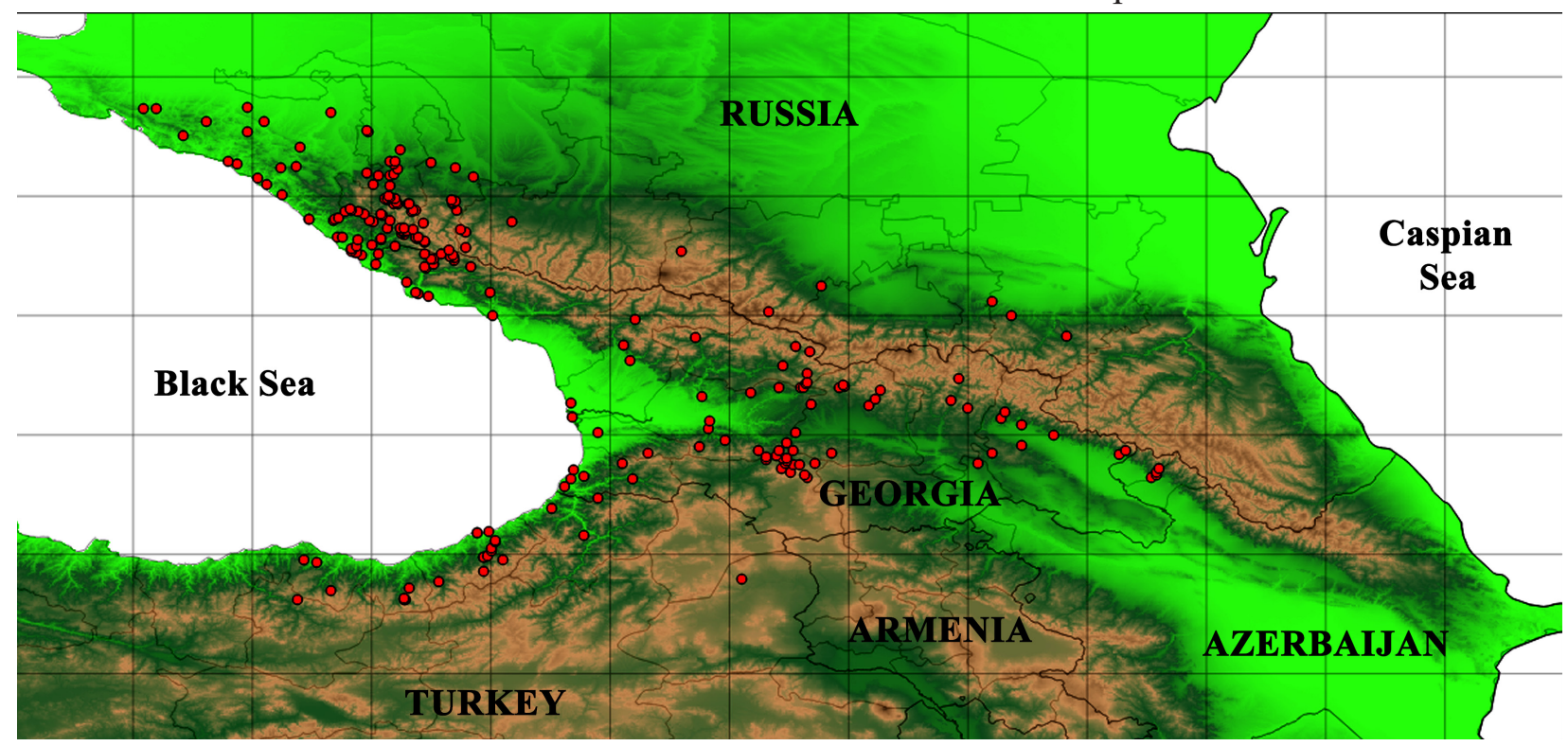

Fig. 2. The distribution map of Pelodytes caucasicus in the Caucasus. Localities of the species are given as red circles. Lowlands are marked in green and mountains are in brown. 


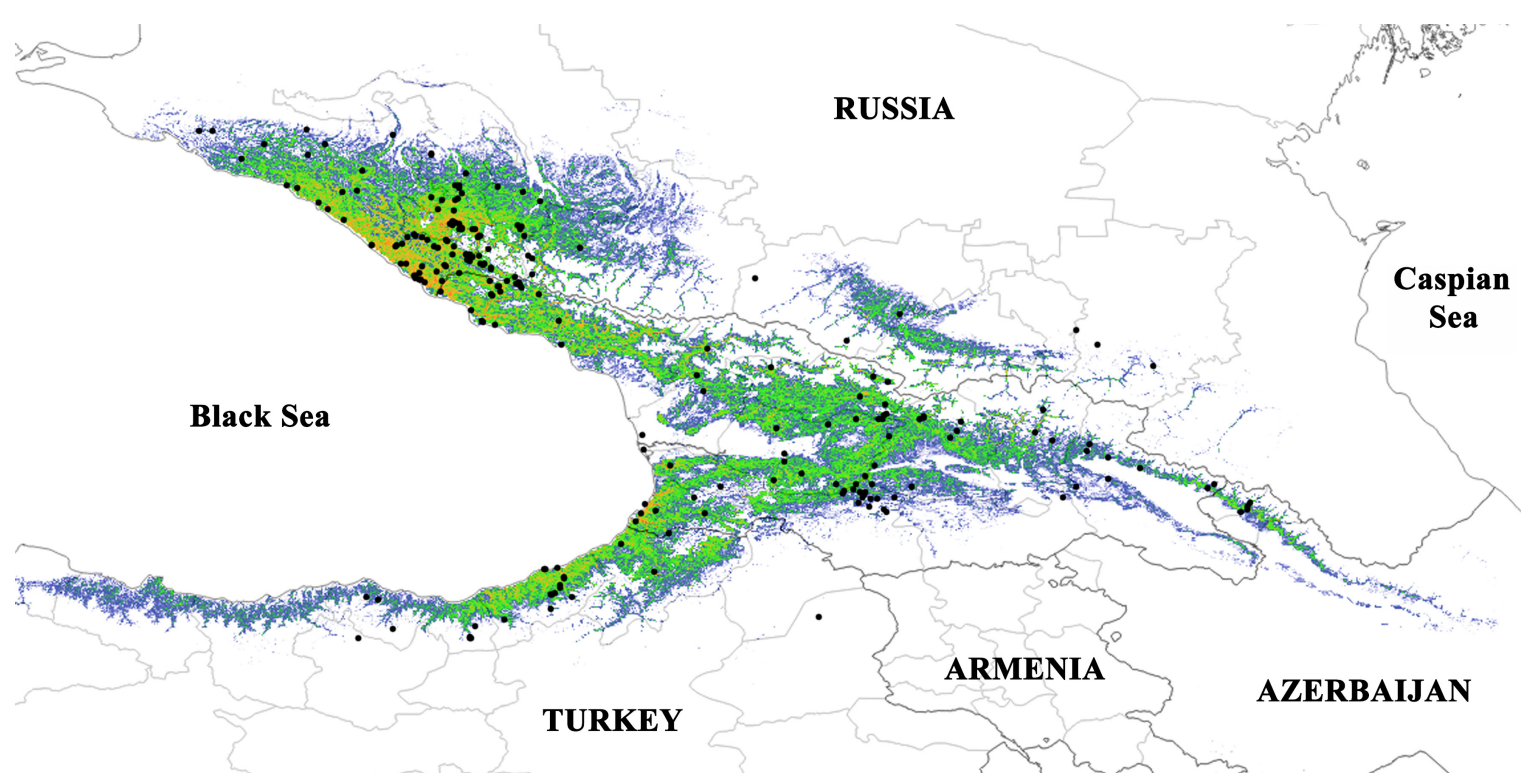

Fig. 3. The predicted potential distribution of Pelodytes caucasicus using MaxEnt. Localities of the species are given as black circles. Most suitable regions are designated by the orange colour (probability of occurrence of the species is $0.5-1.0$ ); moderately suitable are in green and blue $(0.1-0.5)$; and little or unsuitable are in white $(0-0.1)$.

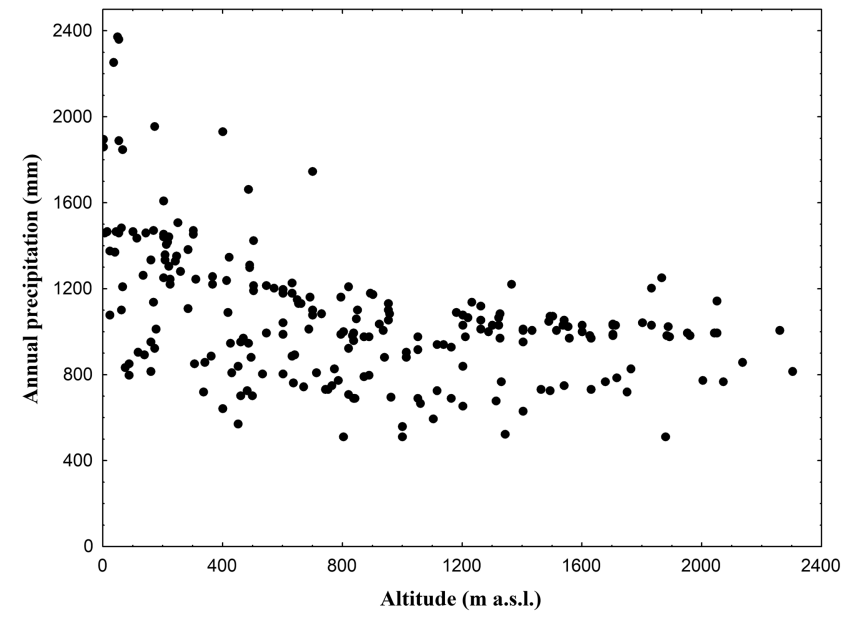

Fig. 4. Distribution of altitude and annual precipitation among localities of Pelodytes caucasicus.

\section{Discussion}

The annual precipitation, which had the highest contribution to the MaxEnt model obtained, plays a very important role for the species survival. According to our and previously published data (Golubev, 1980; Gül, 2014), Pelodytes caucasicus inhabits very wet terrestrial biotopes (Fig. 5), such as shores and banks of ponds and streams with a completely shaded, dense vegetation (trees, bushes and grasses). Usually, the frog was found in dark humid broad-leaved and mixed coniferous-deciduous forests, and it was only sometimes found in more open coniferous forests, as well as subalpine and alpine zones (Golubev, 1985; Dzuev \& Ivanov, 2000; Tuniyev \& Tuniyev, 2012; Lotiev \& Tuniyev, 2017; Tuniyev, 2018). Pelodytes caucasicus breeds in pools along river banks, backwaters and creeks located deep in the forests, far from its boundaries (Golubev, 1980; Kuzmin, 2013).

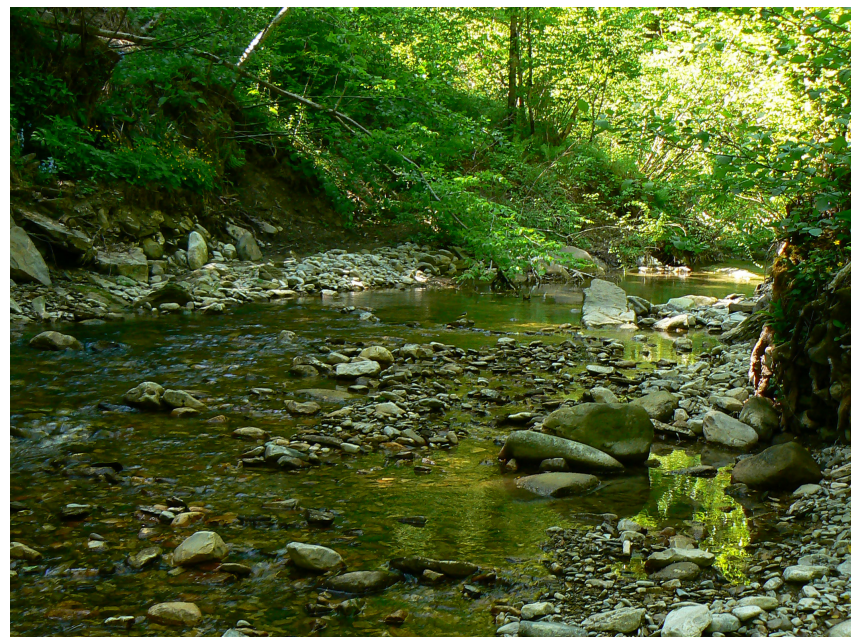

Fig. 5. The breeding habitat of Pelodytes caucasicus in River Makopse, Krasnodarsky Krai, Russia (May 2012).

We have compared the ecological preferences of Pelodytes caucasicus with other Caucasian forest amphibian species studied with MaxEnt. The precipitation parameter has the greatest influence on the range of Lissotriton lantzi only (Skorinov et al., 2014). The precipitation of the warmest quarter strongly influences $(58.2 \%)$ the distributional pattern of the species. A notable contribution of the precipitation of the driest month $(20 \%)$ was revealed for Ommatotriton ophryticus as well (Litvinchuk, 2017). In contrast, only the thermal parameter (isothermality) has the highest percentage contribution for Mertensiella caucasica (Gül et al., 2018).

The distributional range of Pelodytes caucasicus is precisely restricted, being limited to woodland areas (Tarkhnishvili \& Gokhelashvili, 1999). For example, Tuniyev (1990) noted that populations from Lagodekhi and Zakataly regions in eastern Georgia and 
western Azerbaijan are isolated from the main range. However, our results of the MaxEnt modelling (Fig. 3 ) shows that these populations are connected with the main range. On the other hand, we have found that populations which inhabit the central part of the North Caucasus (Kabardino-Balkaria, North OssetiaAlania and Chechnya republics of Russia) could be isolated. Moreover, some of the local records (Khabaz in Kabardino-Balkaria, Martanka and Gekhi rivers in Chechnya) are placed in regions with little suitable habitats (probability of occurrence is $0.02-0.07$ ).

It is important to note that a locality from the vicinities of Kars City in eastern Turkey (number 220 in the Appendix) seems to be wrong, being located under unsuitable environmental conditions (probability of occurrence is 0.01 ), which confirms the opinion previously expressed by Franzen (1999).

Pelodytes caucasicus is relatively common in the West Caucasus and rarer in eastern peripheral populations (Tarkhnishvili \& Gokhelashvili, 1999). As with other Caucasian amphibians, the most important factor limiting the abundance of the species is a lack of appropriate breeding sites. The forest cutting is the main threat, causing a fragmentation of the range and, potentially, an extinction of local populations (Golubev, 1980; Tuniyev, 1985; Tarkhnishvili \& Gokhelashvili, 1999). Destruction and contamination of water bodies by pesticides, mineral fertilisers and cattle, clearing of forests from fallen trees, destroying of litter and mortality on roads also strongly threatens the species (Golubev, 1980, 1981, 1985; Bozhanskiy \& Semenov, 1981; Franzen, 1999, 2012; Dzuev \& Ivanov, 2000; Lotiev, 2007; Kaya et al., 2009). Predatory fishes, adult newts (Ommatotriton ophryticus), larvae of salamanders (Mertensiella caucasica), snakes (Natrix), crabs (Potamon potamios (Olivier, 1804)), beetles (Dytiscus marginalis Linnaeus, 1758), shrews (Neomys fodiens (Pennant, 1771)), and tadpoles of coexisting anurans can consume eggs, larvae and adults of $P$. caucasicus (Tarkhnishvili \& Gokhelashvili, 1999). However, the introduced North American raccoon (Procyon lotor (Linnaeus, 1758)) has the greatest impact on populations of $P$. caucasicus. In shallow water bodies, it can prey most spawning frogs (Lotiev, 2007; Tuniyev \& Tuniyev, 2012).

Undoubtedly, Pelodytes caucasicus should be included in Red Data Books of all regions which it inhabits (including Abkhazia and Turkey). The species needs protection in several nature reserves within all regions where it was found (Darevsky, 1987; Kaya et al., 2009; Kuzmin, 2013). For conservation of the species, it is necessary to identify spawning water bodies and organise micro-reserves (Tarkhnishvili \& Gokhelashvili, 1999; Tuniyev \& Tuniyev, 2017). Puddles and ditches along poorly exploited forest roads are often used by the Caucasian parsley frog as breeding sites (Golubev, 1980). Therefore, to enlarge the population of this species, the best solution would be digging of new water bodies in such places. Additionally, it is necessary to create shelters from fallen cripples and trees near breeding sites and, perhaps, organise protection of spawning sites against raccoons with use of mesh fences.

\section{Acknowledgments}

We are grateful to G. Gasymova, K.D. Milto and O.S. Bezman-Moseyko, who provided us valuable information about the distribution of Pelodytes cancasicus. The work was supported by the RFBR grant (15-29-02546).

\section{References}

Arntzen J.W., Recuero E., Canestrelli D., Martinez-Solano I. 2013. How complex is the Bufo bufo species group? Molecular Phylogenetics and Evolution 69(3): 1203 1208. DOI: 10.1016/j.ympev.2013.07.012

Askenderov A.D. 2017. Amphibians of Dagestan: Distribution, Ecology, Conservation. PhD Thesis. Togliatti. 226 p. [In Russian]

Bombi P., Luiselli L., Capula M., Salvi D. 2009. Predicting elusiveness: potential distribution model of the Southern smooth snake, Coronella girondica, in Italy. Acta Herpetologica 4(1): 7-13. DOI: 10.13128/Acta_Herpetol-2950

Bozhanskiy A.T., Semenov D.V. 1981. Biology of breeding of the Caucasian parsley frog. In: Biological Aspects of Protection of Rare Animals. Moscow. P. 75-78. [In Russian]

Brito J.C., Fahd S., Martínez-Freírea F., Tarroso P., Larbes S., Pleguezuelos J.M., Santos X. 2011. Climate change and peripheral populations: predictions for a relict Mediterranean viper. Acta Herpetologica 6(1): 105-118. DOI: 10.13128/Acta_Herpetol-9583

Darevsky I.S. 1987. Conservation of amphibians and reptiles in nature reserves of the Caucasus. In: Amphibians and Reptiles of Protected Areas. Moscow. P. 85-101. [In Russian]

Doronin I.V. 2013. The Caucasian parsley frog, Pelodytes caucasicus Boulenger, 1896. In: Red Data Book of the Karachay-Cherkessia Republic. Cherkessk: Nartizdat. P. 75. [In Russian]

Duan R.-Y., Kong X.-Q., Huang M.-Y., Varela S., Ji X. 2016. The potential effects of climate change on amphibian distribution, range fragmentation and turnover in China. PeerJ 4: e2185. DOI 10.7717/peerj. 2185

Dufresnes C., Litvinchuk S.N., Leuenberger J., Ghali K., Zinenko O., Stöck M., Perrin N. 2016. Evolutionary melting pots: a biodiversity hotspot shaped by ring diversifications around the Black Sea in the Eastern 
tree frog (Hyla orientalis). Molecular Ecology 25(17): 4285-4300. DOI: 10.1111/mec.13706

Dzuev R.I., Ivanov I.V. 2000. The Caucasian parsley frog, Pelodytes caucasicus Boulenger, 1896. In: Red Data Book of the Kabardino-Balkaria Republic. Nalchik: El'Fa. P. 154-155. [In Russian]

Elith J. 2002. Quantitative methods for modeling species habitat: comparative performance and an application to Australian plants. In: Quantitative Methods for Conservation Biology. New York: Springer. P. 39-58. DOI: 10.1007/0-387-22648-6_4

Franzen M. 1999. Verbreitung und Ökologie von Pelodytes caucasicus Boulenger, 1896 in der Türkei. Salamandra, Rheinbach 35(1): 1-18.

Franzen M. 2012. Pelodytes caucasicus Boulenger, 1896 Kaukasischer Schlammtaucher. In: Handbuch der Reptilien und Amphibien Europas, Band 5/1: Froschlurche (Anura) I (Alytidae, Bombinatoridae, Pelodytidae, Pelobatidae). Wiebelsheim: Aula-Verlag. P. 367-395.

Garcia-Porta J., Litvinchuk S.N., Crochet P.A., Romano A., Geniez Ph., Lo-Valvo M., Lymberakis P., Carranza S. 2012. Molecular phylogenetics and historical biogeography of the west-palearctic common toads (Bufo bufo species complex). Molecular Phylogenetics and Evolution 63(1): 113-130. DOI: 10.1016/j.ympev.2011.12.019

Golubev N.S. 1980. On distribution of the Caucasian parsley frog Pelodytes caucasicus (Amphibia, Pelobatidae). Vestnik Zoologii 3: 52-55. [In Russian]

Golubev N.S. 1981. Breeding of the Caucasian parsley frog - Pelodytes caucasicus (Amphibia, Pelobatidae). Zoologicheskii Zhurnal 60: 1645-1648. [In Russian]

Golubev N.S. 1985. The Caucasian Parsley Frog - Pelodites caucasicus Boulenger (Distribution, Morphology, Ecology). PhD Thesis. Leningrad: Zoological Institute of AN SSSR. 306 p. [In Russian]

Gül S. 2014. Habitat preferences of endemic Caucasian parsley frog (Pelodytes caucasicus) Boulenger, 1896 and Caucasian salamander (Mertensiella caucasica) (Waga, 1876) based on bioclimatic data of Firtına Valley (Rize, Northeastern Anatolia). Anadolu Doğa Bilimleri Dergisi 5(2): 24-29.

Gül S., Kumlutaş Y., Ilgaz Ç. 2018. Potential distribution under different climatic scenarios of climate change of the vulnerable Caucasian salamander (Mertensiella caucasica): A case study of the Caucasus Hotspot. Biologia 73(2): 175-184. DOI: 10.2478/s11756-018-0020-y

Hernandez P.A., Graham C.H., Master L.L., Albert D.L. 2006. The effect of sample size and species characteristics on performance of different species distribution modeling methods. Ecography 29(5): 773-785. DOI: 10.1111/j.0906-7590.2006.04700.x

Iannella M., Cerasoli F., Biondi M. 2017. Unraveling climate influences on the distribution of the parapatric newts Lissotriton vulgaris meridionalis and L. italicus. Frontiers in Zoology 14: 55. DOI: 10.1186/s12983-017-0239-4

Iğci N., Akman B., Göçmen B., Adakul A., Oğuz M.A. 2013. A new locality record of Caucasian parsley frog, Pelo- dytes caucasicus Boulenger, 1896 (Amphibia: Anura: Pelodytidae) in the eastern Black Sea region of Anatolia. Biharean Biologist 7(1): 54-56.

Kacharava W. (Ed.). 1982. Red Data Book of Georgian SSR. Tbilisi: Sabchota Sarkatvelo. 256 p. [In Georgian]

Kaya U., Tuniyev B., Tuniyev S., Kuzmin S., Tarkhnishvili D., Papenfuss T., Sparreboom M., Ugurtas I., Anderson S., Eken G., Kiliç T., Gem E. 2009. Pelodytes caucasicus. In: The IUCN Red List of Threatened Species 2009. Available from http://dx.doi.org/10.2305/IUCN. UK.2009.RLTS.T39422A10236383.en

Kuzmin S.L. 2000. The Caucasian parsley frog, Pelodytes caucasicus Boulenger, 1838. In: Red Data Book of Russian Federation. Animals. Moscow: AST Astrel. P. 317-318. [In Russian]

Kuzmin S.L. 2013. The Amphibians of the Former Soviet Union. Revised Second Edition. Sofia - Moscow: Pensoft. 384 p.

Litvinchuk S.N. 2017. Distribution and conservation status of the banded newt, Ommatotriton ophryticus (Amphibia: Caudata). Nature Conservation Research 2(1): 33-39. DOI: 10.24189/ncr.2017.054 [In Russian]

Litvinchuk S.N., Borkin L.J. 2009. Evolution, Systematics and Distribution of Crested Newts (Triturus cristatus complex) in the Territory of Russia and Adjacent Countries. St. Petersburg: Evropeyskiy dom. 592 p. [In Russian]

Litvinchuk S.N., Borkin L.J., Skorinov D.V., Rosanov J.M. 2008. A new species of common toads from the Talysh Mountains, south-eastern Caucasus: genome size, allozyme, and morphological evidences. Russian Journal of Herpetology 15(1): 19-43.

Litvinchuk S.N., Crottini A., Federici S., De Pous P., Donaire D., Andreone F., Kalezić M.L., Džukić G., Lada G.A., Borkin L.J., Rosanov J.M. 2013. Phylogeographic patterns of genetic diversity in the common spadefoot toad, Pelobates fuscus (Anura: Pelobatidae), reveals evolutionary history, postglacial range expansion and secondary contact. Organisms, Diversity \& Evolution 13(3): 433-451. DOI: 10.1007/s13127-013-0127-5

Lotiev K.Y. 2007. The Caucasian parsley frog, Pelodytes caucasicus Boulenger, 1896. In: Red Data Book of Chechnya Republic. Rare and Threatened Species of Plants and Animals. Groznyi: Southern Publishing House. P. 271-272. [In Russian]

Lotiev L.Y., Tuniyev B.S. 2017. The Caucasian parsley frog, Pelodytes caucasicus Boulenger, 1896. In: Red Data Book of South Ossetia. Nalchik: Poligrafservis i T. P. 218-219. [In Russian]

Lyet A., Thuiller W., Cheylan M., Besnard A. 2013. Finescale regional distribution modelling of rare and threatened species: bridging GIS Tools and conservation in practice. Diversity and Distributions 19(7): 651-663. DOI: $10.1111 /$ ddi.12037

Phillips S.J., Dudík M. 2008. Modeling of species distributions with Maxent: new extensions and a compre- 
hensive evaluation. Ecography 31(2): 161-175. DOI: 10.1111/j.0906-7590.2008.5203.x

Phillips S.J., Anderson R.P., Schapire R.E. 2006. Maximum entropy modeling of species geographic distributions. Ecological Modelling 190(3-4): 231-259. DOI: 10.1016/j.ecolmodel.2005.03.026

Skorinov D.V., Doronin I.V., Kidov A.A., Tuniyev B.S., Litvinchuk S.N. 2014. Distribution and conservation status of the Caucasian newt, Lissotriton lantzi (Wolterstorff, 1914). Russian Journal of Herpetology 21(4): 251-268.

Swets K. 1988. Measuring the accuracy of diagnostic systems. Science 240(4857): 1285-1293.

Tarkhnishvili D.N., Gokhelashvili R.K. 1999. The amphibians of the Caucasus. Advances in Amphibian Research in the Former Soviet Union 4: 1-212.

Tarkhnishvili D., Kaya U., Gavashelishvili A., Serbinova I. 2008. Ecological divergence between two evolutionary lineages of the Caucasian salamander: evidence from GIS analysis. Herpetological Journal 18: 155-163.

Tarkhnishvili D., Gavashelishvili A., Mumladze L. 2012. Palaeoclimatic models help to understand current distribution of Caucasian forest species. Biological Journal of the Linnean Society 105(1): 231-248. DOI: 10.1111/j.1095-8312.2011.01788.x

Tosonoğlu M., Taskavak E. 2004. A preliminary study on morphology and serology of Pelodytes caucasicus Boulenger, 1896 populations from North-Eastern Turkey. Pakistan Journal of Biological Sciences 7(7): 11861190. DOI: $10.3923 /$ pjbs.2004.1186.1190

Tuniyev B.S. 1985. Rare and threatened amphibians and reptiles of the Caucasian Nature Reserve. In: Ecological Studies in the Caucasian Biosphere Reserve. Rostov-onDon: Rostov State University. P. 104-116. [In Russian]

Tuniyev B.S. 1990. On the independence of the Colchis center of amphibian and reptile speciation. Asiatic Herpetological Research 3: 67-84.

Tuniyev B.S. 2018. Modern state of herpetofauna of the Ritsa Relic National Park and new faunistic records in the Abkhazia Republic. Proceedings of the Ritsa Relic National Park 1: 119-129. [In Russian]

Tuniyev B.S., Tuniyev S.B. 2012. The Caucasian parsley frog - Pelodytes caucasicus Boulenger, 1896. In: Red Data Book of Republic of Adygheya. Rare and Threatened Representatives of the Regional Fauna and Flora. $2^{\text {nd }}$ Edition. Maykop: Kachestvo. P. 235-236. [In Russian]

Tuniyev B.S., Tuniyev S.B. 2017. The Caucasian parsley frog Pelodytes caucasicus Boulenger, 1896. In: Red Data Book of Krasnodarsky Krai. Animals. $3^{\text {rd }}$ Edition. Krasnodar. P. 482-484. [In Russian]

Tuniyev B.S., Lotiev K.Yu., Tuniyev S.B., Gabaev V.N., Kidov A.A. 2017. Amphibians and reptiles of South Os- setia. Nature Conservation Research 2(2): 1-23. DOI: 10.24189/ncr.2017.002 [In Russian]

Udovkin S.I., Lipkovich A.D. 1999. The Caucasian parsley frog Pelodytes caucasicus Boulenger, 1896. In: Red Data Book of North Ossetia-Alania. Rare and Threatened Species of Plants and Animals. Vladikavkaz: Proekt-Press. P. 193. [In Russian]

van Riemsdijk I., Arntzen J.W., Bogaerts S., Franzen M., Litvinchuk S.N., Olgun K., Wielstra B. 2017. The Near East as a cradle of biodiversity: a phylogeography of banded newts (genus Ommatotriton) reveals extensive inter- and intraspecific genetic differentiation. Molecular Phylogenetics and Evolution 114: 73-81. DOI: 10.1016/j.ympev.2017.05.028

Vences M., Brown J.L., Lathrop A., Rosa G.M., Cameron A., Crottini A., Dolch R., Edmonds D., Freeman K.L.M., Glaw F., Grismer L.L., Litvinchuk S., Milne M.G., Moore M., Solofo J.F., Noël J., Nguyen T.Q., Ohler A., Randrianantoandro C., Raselimanana A.P., van Leeuwen P., Wogan G.O.U., Ziegler T., Andreone F., Murphy R.W. 2017. Tracing a toad invasion: lack of mitochondrial DNA variation, haplotype origins, and potential distribution of introduced Duttaphrynus melanostictus in Madagascar. Amphibia-Reptilia 38(2): 197-207. DOI: 10.1163/15685381-00003104

Warren D.L., Glor R.E., Turelli M. 2010. ENMTools: a toolbox for comparative studies of environmental niche models. Ecography 33(3): 607-611. DOI: 10.1111/j.1600-0587.2009.06142.x

Wetterings R., Vetter K.C. 2018. Invasive house geckos (Hemidactylus spp.): their current, potential and future distribution. Current Zoology 64(3). DOI: 10.1093/cz/zox052

Wielstra B., Crnobrnja-Isailović J., Litvinchuk S.N., Reijnen B., Skidmore A.K., Sotiropoulos K., Toxopeus A.G., Tzankov N., Vukov T., Arntzen J.W. 2013a. Tracing glacial refugia of Triturus newts based on mitochondrial DNA phylogeography and species distribution modeling. Frontiers in Zoology 10(1): 13. DOI: 10.1186/1742-9994-10-13

Wielstra B., Litvinchuk S.N., Naumov B., Tzankov N. Arntzen J.W. 2013b. A revised taxonomy of crested newts in the Triturus karelinii group (Amphibia: Caudata: Salamandridae), with the description of a new species. Zootaxa 3682(3): 441-453. DOI: 10.11646/ zootaxa.3682.3.5

Zinenko A.I., Goncharenko L.A. 2009. Catalogue of Collections of the Museum of Nature at V.N. Karazin's Kharkiv National University. Amphibians (Amphibia). Reptiles (Reptilia): Crocodiles (Crocodylia), Turtles (Testudines). Kharkiv: V.N. Karazin Kharkiv National University. [In Russian] 
Appendix. GIS-referenced list of localities of Pelodytes caucasicus.

Abkhazia (21 localities)

1: Salme, $\sim 40.038^{\circ} \mathrm{E}, 43.426^{\circ} \mathrm{N}, \sim 100 \mathrm{~m}$; 2: Gagra, $\sim 40.290^{\circ} \mathrm{E}, 43.282^{\circ} \mathrm{N}, \sim 500 \mathrm{~m}$; 3: Pitsunda-Myusserskiy Nature Reserve, $\sim 40.371^{\circ} \mathrm{E}, 43.191^{\circ} \mathrm{N}, \sim 41 \mathrm{~m} ; 4$ : Pitsunda, $\sim 40.385^{\circ} \mathrm{E}, 43.178^{\circ} \mathrm{N}, \sim 13 \mathrm{~m}$; 5: Myussera, $\sim 40.478^{\circ} \mathrm{E}, 43.160^{\circ} \mathrm{N}, \sim 50 \mathrm{~m}$; 6: Patara (= Malaya) Ritsa Lake, $\sim 40.502^{\circ} \mathrm{E}, 43.476^{\circ} \mathrm{N}, \sim 1260 \mathrm{~m}$; 7: Avadkhara (=Auadkhara) River, $\sim 40.658^{\circ} \mathrm{E}, 43.500^{\circ} \mathrm{N}, 1500 \mathrm{~m}$; 8: Pskhu Nature Reserve, $\sim 40.833^{\circ} \mathrm{E}, 43.412^{\circ} \mathrm{N}, \sim 890 \mathrm{~m}$; 9: Gumistinskiy Nature Reserve, $\sim 40.996^{\circ} \mathrm{E}, 43.190^{\circ} \mathrm{N}$, $\sim 245 \mathrm{~m}$; 10: Sukhumi, $41.017^{\circ} \mathrm{E}, 43.000^{\circ} \mathrm{N}, \sim 6 \mathrm{~m} ; 11$ : Gega River canion, $\sim 40.447^{\circ} \mathrm{E}, 43.410^{\circ} \mathrm{N}, \sim 490 \mathrm{~m}$; 12: Agepsta Mt., $\sim 40.443^{\circ} \mathrm{E}, 43.521^{\circ} \mathrm{N}, \sim 1700 \mathrm{~m} ; 13$ : Bzyp' River canion, $\sim 40.459^{\circ} \mathrm{E}, 43.393^{\circ} \mathrm{N}, \sim 220 \mathrm{~m} ; 14$ : Yupshara River canion, $\sim 40.520^{\circ} \mathrm{E}, 43.425^{\circ} \mathrm{N}, \sim 500 \mathrm{~m}$; 15: Audkhara resort, $\sim 40.662^{\circ} \mathrm{E}, 43.498^{\circ} \mathrm{N}, \sim 1490 \mathrm{~m}$; 16: Lashipse Ridge, $\sim 40.676^{\circ} \mathrm{E}, 43.511^{\circ} \mathrm{N}, \sim 1540 \mathrm{~m}$; 17: Mzym Lake, $\sim 40.579^{\circ} \mathrm{E}, 43.521^{\circ} \mathrm{N}, \sim 2050 \mathrm{~m} ; 18$ : Pyv Pass, $\sim 40.687^{\circ} \mathrm{E}, 43.488^{\circ} \mathrm{N}, \sim 1885 \mathrm{~m}$; 19: Chkhy Lake, $\sim 40.692^{\circ} \mathrm{E}, 43.465^{\circ} \mathrm{N}, \sim 2260 \mathrm{~m} ; 20$ : Between Bol'shaya Ritsa and Patara Ritsa lakes, $40.515^{\circ} \mathrm{E}$, $43.475^{\circ} \mathrm{N}, \sim 1230 \mathrm{~m} ; 21$ : Kutikhug Ridge, $\sim 40.646^{\circ} \mathrm{E}$, $43.546^{\circ} \mathrm{N}, \sim 1950 \mathrm{~m}$.

\section{Azerbaijan (4 localities)}

22: Katex, $\sim 46.536^{\circ} \mathrm{E}, 41.643^{\circ} \mathrm{N}, \sim 335 \mathrm{~m} ; 23$ : Gabizdara, $\sim 46.584^{\circ} \mathrm{E}, 41.688^{\circ} \mathrm{N}, \sim 530 \mathrm{~m} ; 24$ : Zagatala State Reserve, Gumukh-Dere River, $\sim 46.604^{\circ} \mathrm{E}, 41.714^{\circ} \mathrm{N}$, $\sim 600 \mathrm{~m} ; 25$ : Mazix, $46.585^{\circ} \mathrm{E}, 41.668^{\circ} \mathrm{N}, \sim 430 \mathrm{~m}$.

\section{Georgia (56 localities)}

26: Mtirala Mt., $\sim 41.783^{\circ} \mathrm{E}, 41.650^{\circ} \mathrm{N}, \sim 900$ $\mathrm{m} ;$ 27: Borjomi, $10 \mathrm{~km} \mathrm{SSE}, \sim 43.479^{\circ} \mathrm{E}, 41.780^{\circ} \mathrm{N}$, $\sim 1492 \mathrm{~m} ; 28$ : Charnali River, $\sim 41.621^{\circ} \mathrm{E}, 41.569^{\circ} \mathrm{N}$, $\sim 35 \mathrm{~m} ;$ 29: Batumi, $\sim 41.667^{\circ} \mathrm{E}, 41.633^{\circ} \mathrm{N}, \sim 50 \mathrm{~m}$; 30: Kulevi, $\sim 41.674^{\circ} \mathrm{E}, 42.270^{\circ} \mathrm{N}, \sim 0 \mathrm{~m} ; 31$ : Poti, $\sim 41.683^{\circ} \mathrm{E}, 42.150^{\circ} \mathrm{N}, \sim 2 \mathrm{~m}$; 32: Batumi botanical garden, $\sim 41.695^{\circ} \mathrm{E}, 41.707^{\circ} \mathrm{N}, \sim 47 \mathrm{~m} ; 33$ : Kolkhida Nature Reserve, $\sim 41.900^{\circ} \mathrm{E}, 42.017^{\circ} \mathrm{N}, \sim 170 \mathrm{~m} ; 34$ : Kintrishskiy Nature Reserve, $\sim 42.098^{\circ} \mathrm{E}, 41.766^{\circ} \mathrm{N}$, $\sim 1830 \mathrm{~m}$; 35: Kvira, $\sim 42.117^{\circ} \mathrm{E}, 42.750^{\circ} \mathrm{N}, \sim 1365$ m; 36: Mukhuri, $\sim 42.168^{\circ} \mathrm{E}, 42.624^{\circ} \mathrm{N}, \sim 250 \mathrm{~m} ; 37$ : Shuakhevi, $\sim 42.183^{\circ} \mathrm{E}, 41.633^{\circ} \mathrm{N}, \sim 885 \mathrm{~m}$; 38: Inguri River, $\sim 42.207^{\circ} \mathrm{E}, 42.968^{\circ} \mathrm{N}, \sim 660 \mathrm{~m}$; 39: Bakhmaro, $\sim 42.317^{\circ} \mathrm{E}, 41.850^{\circ} \mathrm{N}, \sim 1866 \mathrm{~m} ; 40$ : Lentekhi, $\sim 42.717^{\circ} \mathrm{E}, 42.817^{\circ} \mathrm{N}, \sim 1177 \mathrm{~m}$; 41: Sairme, $42.743^{\circ} \mathrm{E}$, $41.904^{\circ} \mathrm{N}, \sim 938 \mathrm{~m} ; 42$ : Kurusebi, $\sim 42.767^{\circ} \mathrm{E}$, $42.317^{\circ} \mathrm{N}, \sim 363 \mathrm{~m} ; 43$ : Mayakovskiy, $\sim 42.827^{\circ} \mathrm{E}$, $42.054^{\circ} \mathrm{N}, \sim 222 \mathrm{~m} ; 44$ : Bagdadi, $\sim 42.833^{\circ} \mathrm{E}, 42.117^{\circ} \mathrm{N}$, $\sim 200 \mathrm{~m} ; 45$ : Khani, $\sim 42.967^{\circ} \mathrm{E}, 41.950^{\circ} \mathrm{N}, \sim 886 \mathrm{~m}$; 46: Khreiti, $\sim 43.183^{\circ} \mathrm{E}, 42.350^{\circ} \mathrm{N}, \sim 868 \mathrm{~m}$; 47: Chitakhevi, $43.303^{\circ} \mathrm{E}, 41.791^{\circ} \mathrm{N}, \sim 838 \mathrm{~m}$; 48: Green Monastery, $\sim 43.310^{\circ} \mathrm{E}, 41.811^{\circ} \mathrm{N}, \sim 960 \mathrm{~m} ; 49$ : Borjomi, $43.393^{\circ} \mathrm{E}, 41.826^{\circ} \mathrm{N}, 837 \mathrm{~m}$; 50: Kvereti, $\sim 43.411^{\circ} \mathrm{E}$, $42.392^{\circ} \mathrm{N}, \sim 818 \mathrm{~m} ;$ 51: Rveli, Baniskhevi River, $\sim 43.412^{\circ} \mathrm{E}, 41.873^{\circ} \mathrm{N}, \sim 818 \mathrm{~m} ; 52$ : Tsikhisdzvari, $\sim 43.433^{\circ} \mathrm{E}, 41.717^{\circ} \mathrm{N}, \sim 1627 \mathrm{~m}$; 53: Oni, $\sim 43.443^{\circ} \mathrm{E}$, $42.579^{\circ} \mathrm{N}, \sim 837 \mathrm{~m} ; 54:$ Tba, $\sim 43.444^{\circ} \mathrm{E}, 41.800^{\circ} \mathrm{N}$, $\sim 1160 \mathrm{~m}$; 55: Sakochavi, $43.464^{\circ} \mathrm{E}, 41.765^{\circ} \mathrm{N}, \sim 1463$ $\mathrm{m} ;$ 56: Tsagveri, $\sim 43.483^{\circ} \mathrm{E}, 41.800^{\circ} \mathrm{N}, \sim 1050 \mathrm{~m} ; 57$ : Lomis-Mta Mt., $\sim 43.246^{\circ} \mathrm{E}, 41.868^{\circ} \mathrm{N}, 2134 \mathrm{~m}$; 58: Akhaldaba, $\sim 43.412^{\circ} \mathrm{E}, 41.873^{\circ} \mathrm{N}, \sim 750 \mathrm{~m}$; 59: TskhraTskharo Pass, $\sim 43.515^{\circ} \mathrm{E}, 41.689^{\circ} \mathrm{N}, \sim 2300 \mathrm{~m} ; 60$ : Bakuriani, $\sim 43.533^{\circ} \mathrm{E}, 41.750^{\circ} \mathrm{N}, \sim 1676 \mathrm{~m} ; 61$ : Nedzura River, $\sim 43.539^{\circ} \mathrm{E}, 41.865^{\circ} \mathrm{N}, \sim 1115 \mathrm{~m}$; 62: Saglolo, $\sim 43.555^{\circ} \mathrm{E}, 42.736^{\circ} \mathrm{N}, \sim 1286 \mathrm{~m} ; 63$ : Mutarchi, $\sim 43.583^{\circ} \mathrm{E}, 41.750^{\circ} \mathrm{N}, \sim 1540 \mathrm{~m}$; 64: Tabatskuri Lake, $\sim 43.633^{\circ} \mathrm{E}, 41.667^{\circ} \mathrm{N}, 2000 \mathrm{~m} ; 65$ : Nariani, $\sim 43.655^{\circ} \mathrm{E}$, $41.640^{\circ} \mathrm{N}, \sim 2069 \mathrm{~m} ; 66$ : Shovi, $\sim 43.671^{\circ} \mathrm{E}, 42.703^{\circ} \mathrm{N}$, $\sim 1488 \mathrm{~m} ; 67$ : Gudzhareti River, $\sim 43.717^{\circ} \mathrm{E}, 41.767^{\circ} \mathrm{N}$, $\sim 1715 \mathrm{~m} ;$ 68: Surami, $\sim 43.558^{\circ} \mathrm{E}, 42.020^{\circ} \mathrm{N}, \sim 765$ $\mathrm{m} ;$ 69: Kvelantubani, $\sim 43.858^{\circ} \mathrm{E}, 41.846^{\circ} \mathrm{N}, \sim 1330$ $\mathrm{m} ;$ 70: Magaroskari, $\sim 44.863^{\circ} \mathrm{E}, 42.287^{\circ} \mathrm{N}, \sim 956 \mathrm{~m}$; 71: Barisakho, $\sim 44.927^{\circ} \mathrm{E}, 42.472^{\circ} \mathrm{N}, \sim 1323 \mathrm{~m} ; 72$ : Zemo-Artani, $\sim 45.000^{\circ} \mathrm{E}, 42.227^{\circ} \mathrm{N}, \sim 1260 \mathrm{~m} ; 73$ : Akhalsopeli, $\sim 45.084^{\circ} \mathrm{E}, 41.764^{\circ} \mathrm{N}, \sim 840 \mathrm{~m} ; 74$ : Gombori, $\sim 45.200^{\circ} \mathrm{E}, 41.850^{\circ} \mathrm{N}, \sim 1200 \mathrm{~m} ;$ 75: Pankisi, $\sim 45.278^{\circ} \mathrm{E}, 42.143^{\circ} \mathrm{N}, \sim 633 \mathrm{~m} ; 76$ : Birkiani, $\sim 45.305^{\circ} \mathrm{E}$, $42.190^{\circ} \mathrm{N}, \sim 710 \mathrm{~m} ; 77$ : Pshaveli, $\sim 45.450^{\circ} \mathrm{E}, 42.083^{\circ} \mathrm{N}$, $\sim 460 \mathrm{~m}$; 78: Telavi, $\sim 45.454^{\circ} \mathrm{E}, 41.916^{\circ} \mathrm{N}, \sim 785 \mathrm{~m} ; 79$ : Shilda, $\sim 45.717^{\circ} \mathrm{E}, 42.000^{\circ} \mathrm{N}, \sim 496 \mathrm{~m} ; 80$ : Lagodekhi, $\sim 46.267^{\circ} \mathrm{E}, 41.833^{\circ} \mathrm{N}, \sim 480 \mathrm{~m} ; 81$ : Lagodekhi Nature Reserve, $\sim 46.317^{\circ} \mathrm{E}, 41.867^{\circ} \mathrm{N}, \sim 870 \mathrm{~m}$.

\section{Adygea Republic, Russia (25 localities)}

82: Mirnyi, $\sim 39.961^{\circ} \mathrm{E}, 44.546^{\circ} \mathrm{N}, \sim 337 \mathrm{~m} ; 83$ : Maykop, $\sim 39.970^{\circ} \mathrm{E}, 44.544^{\circ} \mathrm{N}, \sim 305 \mathrm{~m}$; 84: Lagonaki, $\sim 40.016^{\circ} \mathrm{E}, 44.096^{\circ} \mathrm{N}, \sim 1627 \mathrm{~m} ; 85$ : Goreloe site, $\sim 40.112^{\circ} \mathrm{E}, 43.981^{\circ} \mathrm{N}, \sim 730 \mathrm{~m}$; 86: Suvorovskiy check point of Kavkazskiy Nature Reserve, $40.133^{\circ} \mathrm{E}$, $43.967^{\circ} \mathrm{N}, \sim 1400 \mathrm{~m} ; 87$ : Zabrookennykh ravine, $\sim 40.136^{\circ} \mathrm{E}, 43.983^{\circ} \mathrm{N}, \sim 843 \mathrm{~m} ; 88$ : Guzeripl check point, $40.138^{\circ} \mathrm{E}, 43.996^{\circ} \mathrm{N}, 700 \mathrm{~m}$; 89: Khamyshki, Lipovaya River, $\sim 40.150^{\circ} \mathrm{E}, 44.092^{\circ} \mathrm{N}, \sim 600 \mathrm{~m}$; 90: Nikel, Syuk River, $40.154^{\circ} \mathrm{E}, 44.174^{\circ} \mathrm{N}, 800 \mathrm{~m}$; 91: Guzeripl, $3 \mathrm{~km}$ to Abago pastury, $40.154^{\circ} \mathrm{E}, 43.987^{\circ} \mathrm{N}$, $\sim 844$ m; 92: Aminovka River, $40.154^{\circ} \mathrm{E}, 44.293^{\circ} \mathrm{N}$, $\sim 483$ m; 93: Gruzinka River, $\sim 40.183^{\circ} \mathrm{E}, 44.183^{\circ} \mathrm{N}$, $\sim 544$ m; 94: Rufabgo waterfalls, $\sim 40.187^{\circ} \mathrm{E}, 44.269^{\circ} \mathrm{N}$, $\sim 460$ m; 95: Kamennomostskiy, $\sim 40.192^{\circ} \mathrm{E}, 44.296^{\circ} \mathrm{N}$, $\sim 423 \mathrm{~m}$; 96: Dakhovskaya, $\sim 40.213^{\circ} \mathrm{E}, 44.227^{\circ} \mathrm{N}, \sim 468$ m; 97: Abadzekhskaya, $40.243^{\circ} \mathrm{E}, 44.389^{\circ} \mathrm{N}, \sim 360 \mathrm{~m}$; 98: Turovaya River mouth, $\sim 40.188^{\circ} \mathrm{E}, 43.934^{\circ} \mathrm{N}, 950$ m; 99: Guzeripl, $7 \mathrm{~km}$ to Abago pastury, $40.193^{\circ} \mathrm{E}$, $43.977^{\circ} \mathrm{N}, \sim 1430 \mathrm{~m} ; 100$ : Abago pastury, $\sim 40.211^{\circ} \mathrm{E}$, $43.950^{\circ} \mathrm{N}, 1700 \mathrm{~m}$; 101: Ekspeditsiya Mt., $40.216^{\circ} \mathrm{E}$, 
$43.940^{\circ} \mathrm{N}, \sim 1880 \mathrm{~m} ; 102$ : Tyaginya point, $\sim 40.300^{\circ} \mathrm{E}$, $43.933^{\circ} \mathrm{N}, \sim 1624 \mathrm{~m} ; 103$ : Gefo Mt., $\sim 40.317^{\circ} \mathrm{E}$, $43.933^{\circ} \mathrm{N}, \sim 1888 \mathrm{~m} ; 104$ : Grustnaya River mouth, $\sim 40.341^{\circ} \mathrm{E}, 43.874^{\circ} \mathrm{N}, \sim 1200 \mathrm{~m}$; 105 : Sennaya glade, $\sim 40.348^{\circ} \mathrm{E}, 43.884^{\circ} \mathrm{N}, 1300 \mathrm{~m}$; 106: Dzugu stream, $\sim 40.367^{\circ} \mathrm{E}, 43.883^{\circ} \mathrm{N}, \sim 1400 \mathrm{~m}$.

\section{Chechnya Republic, Russia (3 localities)}

107: Martanka (= Fortanga) River, $\sim 45.199^{\circ} \mathrm{E}$, $43.119^{\circ} \mathrm{N}, \sim 400 \mathrm{~m} ; 108$ : Gekhi River, $\sim 45.367^{\circ} \mathrm{E}$, $43.000^{\circ} \mathrm{N}, \sim 670 \mathrm{~m}$; 109 : Sharo-Argun River, $\sim 45.823^{\circ} \mathrm{E}$, $42.828^{\circ} \mathrm{N}, \sim 740 \mathrm{~m}$.

Kabardino-Balkaria Republic, Russia (2 localities). 110: Khabaz, Malka River, $\sim 42.595^{\circ} \mathrm{E}, 43.541^{\circ} \mathrm{N}$, $\sim 1760 \mathrm{~m} ;$ 111: Verkhnyaya Balkariya, $15 \mathrm{~km}$ upper, $\sim 43.330^{\circ} \mathrm{E}, 43.035^{\circ} \mathrm{N}, \sim 1555 \mathrm{~m}$.

Karachaevo-Cherkessia Republic, Russia (4 localities)

112. Damkhurts Mt., $\sim 40.748^{\circ} \mathrm{E}, 43.720^{\circ} \mathrm{N}, 1700$ $\mathrm{m} ; 113$ : Zakan, $\sim 40.786^{\circ} \mathrm{E}, 43.699^{\circ} \mathrm{N}, \sim 1322 \mathrm{~m} ; 114$ : Damkhurts River source, $\sim 40.788^{\circ} \mathrm{E}, 43.575^{\circ} \mathrm{N}, \sim 1535$ m; 115: Cheremukhovskiy Nature Rezerve, Urup River, $\sim 41.171^{\circ} \mathrm{E}, 43.783^{\circ} \mathrm{N}, \sim 1050 \mathrm{~m}$.

\section{Krasnodarsky Krai, Russia (73 localities)}

116: Shapsugskiy, $\sim 38.085^{\circ} \mathrm{E}, 44.736^{\circ} \mathrm{N}, \sim 86$ $\mathrm{m} ;$ 117: Erivanskaya, $\sim 38.191^{\circ} \mathrm{E}, 44.732^{\circ} \mathrm{N}, \sim 160$ m; 118: Pshada, $\sim 38.424^{\circ} \mathrm{E}, 44.510^{\circ} \mathrm{N}, \sim 172 \mathrm{~m} ; 119$ : Plancheskaya Shchel', $\sim 38.613^{\circ} \mathrm{E}, 44.630^{\circ} \mathrm{N}, \sim 137 \mathrm{~m}$; 120: Zolotoy Bereg resort, $\sim 38.795^{\circ} \mathrm{E}, 44.287^{\circ} \mathrm{N}, \sim 22$ m; 121: Novomikhailovskiy, $\sim 38.873^{\circ} \mathrm{E}, 44.275^{\circ} \mathrm{N}$, $\sim 60 \mathrm{~m}$; 122: Kaluzhskaya, $\sim 38.957^{\circ} \mathrm{E}, 44.742^{\circ} \mathrm{N}, \sim 87$ m; 123: Khrebtovoe, $\sim 38.962^{\circ} \mathrm{E}, 44.542^{\circ} \mathrm{N}, \sim 160 \mathrm{~m}$; 124: Agoy, $\sim 39.048^{\circ} \mathrm{E}, 44.154^{\circ} \mathrm{N}, \sim 65 \mathrm{~m}$; 125 : Goryachiy Klyuch, $\sim 39.099^{\circ} \mathrm{E}, 44.620^{\circ} \mathrm{N}, \sim 114 \mathrm{~m} ; 126$ : Tuapse, $\sim 39.123^{\circ} \mathrm{E}, 44.097^{\circ} \mathrm{N}, \sim 223 \mathrm{~m} ; 127$ : Chelipsi River mouth, $\sim 39.243^{\circ} \mathrm{E}, 44.240^{\circ} \mathrm{N}, \sim 167 \mathrm{~m} ; 128$ : Makopse River, $39.253^{\circ} \mathrm{E}, 44.017^{\circ} \mathrm{N}, 135 \mathrm{~m} ; 129$ : Goitkh, $\sim 39.364^{\circ} \mathrm{E}, 44.251^{\circ} \mathrm{N}, \sim 285 \mathrm{~m}$; 130: Kurinskaya, $\sim 39.400^{\circ} \mathrm{E}, 44.414^{\circ} \mathrm{N}, \sim 175 \mathrm{~m}$; 131 : Golovinskiy Nature Reserve, $\sim 39.475^{\circ} \mathrm{E}, 43.811^{\circ} \mathrm{N}, \sim 38 \mathrm{~m} ; 132$ : Shakhe, $\sim 39.479^{\circ} \mathrm{E}, 43.805^{\circ} \mathrm{N}, \sim 23 \mathrm{~m}$; 133 : Chernigovskaya, $\sim 39.655^{\circ} \mathrm{E}, 44.704^{\circ} \mathrm{N}, \sim 71 \mathrm{~m}$; 134: Shakhe River, $\sim 39.677^{\circ} \mathrm{E}, 43.799^{\circ} \mathrm{N}, \sim 160 \mathrm{~m}$; 135: Solokh-Aul check point, $\sim 39.685^{\circ} \mathrm{E}, 43.806^{\circ} \mathrm{N}, \sim 207 \mathrm{~m}$; 136: SergeyPole, $\sim 39.716^{\circ} \mathrm{E}, 43.654^{\circ} \mathrm{N}, 200 \mathrm{~m}$; 137: Bzych stream, $\sim 39.724^{\circ} \mathrm{E}, 43.820^{\circ} \mathrm{N}, \sim 204 \mathrm{~m}$; 138 : Sochi, $\sim 39.758^{\circ} \mathrm{E}$, $43.660^{\circ} \mathrm{N}, \sim 140 \mathrm{~m}$; 139 : Azhu River mouth, $\sim 39.774^{\circ} \mathrm{E}$, $43.869^{\circ} \mathrm{N}, \sim 310 \mathrm{~m} ; 140$ : Babuk-Aul check point, $\sim 39.822^{\circ} \mathrm{E}, 43.896^{\circ} \mathrm{N}, 630 \mathrm{~m}$; 141: Agurchik stream, Bol'shoyAkhun Mt., $\sim 39.831^{\circ} \mathrm{E}, 43.561^{\circ} \mathrm{N}, \sim 217 \mathrm{~m} ; 142$ : Bushuyka River mouth, $\sim 39.831^{\circ} \mathrm{E}, 43.882^{\circ} \mathrm{N}, \sim 410 \mathrm{~m}$; 143: Malyi Akhun River, $39.834^{\circ} \mathrm{E}, 43.538^{\circ} \mathrm{N}, 300 \mathrm{~m}$;
144: Khosta, $\sim 39.868^{\circ} \mathrm{E}, 43.528^{\circ} \mathrm{N}, \sim 203 \mathrm{~m}$; 145: Malaya Khosta River, $\sim 39.873^{\circ} \mathrm{E}, 43.583^{\circ} \mathrm{N}, \sim 112 \mathrm{~m}$; 146: Tiso-Samshitovaya grove, $39.876^{\circ} \mathrm{E}, 43.528^{\circ} \mathrm{N}, 58 \mathrm{~m}$; 147: Bushiy (= Bushchego) River mouth, $\sim 39.884^{\circ} \mathrm{E}$, $43.872^{\circ} \mathrm{N}, \sim 500 \mathrm{~m} ; 148$ : Belyi stream, $\sim 39.888^{\circ} \mathrm{E}$, $43.637^{\circ} \mathrm{N}, \sim 490 \quad \mathrm{~m} ; 149$ : Kashtany, $\sim 39.911^{\circ} \mathrm{E}$, $43.509^{\circ} \mathrm{N}, \sim 166 \mathrm{~m} ; 150$ : Shakhe River, $\sim 39.933^{\circ} \mathrm{E}$, $43.855^{\circ} \mathrm{N}, \sim 645 \mathrm{~m} ; 151$ : Mezmay, $\sim 39.963^{\circ} \mathrm{E}$, $44.190^{\circ} \mathrm{N}, \sim 685 \mathrm{~m} ; 152$ : Chernye osypi, $\sim 39.983^{\circ} \mathrm{E}$, $43.800^{\circ} \mathrm{N}, \sim 1710 \mathrm{~m} ; 153$ : Troitse-Georgievskiy monastery, $\sim 40.006^{\circ} \mathrm{E}, 43.590^{\circ} \mathrm{N}, \sim 285 \mathrm{~m} ; 154$ : Bol'shaya Chura Mt., $\sim 40.017^{\circ} \mathrm{E}, 43.783^{\circ} \mathrm{N}, 1800 \mathrm{~m}$; 155: Ermolovka, $\sim 40.051^{\circ} \mathrm{E}, 43.515^{\circ} \mathrm{N}, \sim 208 \mathrm{~m}$; 156: Kamyshanova Polyana, $\sim 40.051^{\circ} \mathrm{E}, 44.169^{\circ} \mathrm{N}, 1210 \mathrm{~m} ; 157$ : Chvezhipse check point, $\sim 40.073^{\circ} \mathrm{E}, 43.644^{\circ} \mathrm{N}, \sim 256 \mathrm{~m}$; 158: Malaya Chura River, $\sim 40.079^{\circ} \mathrm{E}, 43.847^{\circ} \mathrm{N}, 700$ m; 159: Medvezhiy Ugol, $\sim 40.083^{\circ} \mathrm{E}, 43.634^{\circ} \mathrm{N}, \sim 240$ m; 160: Beryozovaya River, $\sim 40.094^{\circ} \mathrm{E}, 43.845^{\circ} \mathrm{N}$, $\sim 950$ m; 161: Achishkho Mt., $\sim 40.133^{\circ} \mathrm{E}, 43.733^{\circ} \mathrm{N}$, $\sim 2040 \mathrm{~m}$; 162: Chugush Ridge, $\sim 40.150^{\circ} \mathrm{E}, 43.800^{\circ} \mathrm{N}$, 1600 m; 163: Aibga Mt., $\sim 40.195^{\circ} \mathrm{E}, 43.586^{\circ} \mathrm{N}, \sim 820$ m; 164: Assara River mouth, $\sim 40.243^{\circ} \mathrm{E}, 43.728^{\circ} \mathrm{N}$, $\sim 688 \mathrm{~m}$; 165: Esto-Sadok, $\sim 40.253^{\circ} \mathrm{E}, 43.692^{\circ} \mathrm{N}, \sim 630$ m; 166: Laura River, apiary, $\sim 40.264^{\circ} \mathrm{E}, 43.701^{\circ} \mathrm{N}$, $600 \mathrm{~m} ;$ 167: Achipse River mouth, $\sim 40.264^{\circ} \mathrm{E}$, $43.707^{\circ} \mathrm{N}, \sim 600 \mathrm{~m} ; 168$ : Rudovaya River, $\sim 40.266^{\circ} \mathrm{E}$, $43.727^{\circ} \mathrm{N}, 850 \mathrm{~m}$; 169 : Laura and Achipse check points, $\sim 40.269^{\circ} \mathrm{E}, 43.698^{\circ} \mathrm{N}, 570 \mathrm{~m} ; 170$ : Psekhako Ridge, $\sim 40.272^{\circ} \mathrm{E}, 43.737^{\circ} \mathrm{N}, \sim 1260 \mathrm{~m}$; 171: Slantsevyi Rudnik, $\sim 40.276^{\circ} \mathrm{E}, 43.681^{\circ} \mathrm{N}, \sim 545 \mathrm{~m}$; 172: Bzerpiya River mouth, $\sim 40.296^{\circ} \mathrm{E}, 43.716^{\circ} \mathrm{N}, \sim 650 \mathrm{~m} ; 173$ : Pslukh River, $\sim 40.364^{\circ} \mathrm{E}, 43.657^{\circ} \mathrm{N}, \sim 795 \mathrm{~m}$; 174: Semikolenka Mt., $\sim 40.383^{\circ} \mathrm{E}, 43.650^{\circ} \mathrm{N}, \sim 1322 \mathrm{~m} ; 175$ : Between Krasnaya Polyana and Pseashkho Pass, $\sim 40.348^{\circ} \mathrm{E}$, $43.725^{\circ} \mathrm{N}, 1219 \mathrm{~m} ; 176$ : Pslukh check point, $\sim 40.390^{\circ} \mathrm{E}$, $43.661^{\circ} \mathrm{N}, 950 \mathrm{~m}$; 177: Urushten River, $\sim 40.431^{\circ} \mathrm{E}$, $43.778^{\circ} \mathrm{N}, 1600 \mathrm{~m}$; 178: Between Aishkha Mt. and Engelmanovy glades, $\sim 40.444^{\circ} \mathrm{E}, 43.627^{\circ} \mathrm{N}, 1700 \mathrm{~m} ; 179$ : Engelmanovy glades, $\sim 40.448^{\circ} \mathrm{E}, 43.618^{\circ} \mathrm{N}, 1200 \mathrm{~m}$; 180: Barakaevskaya, $\sim 40.502^{\circ} \mathrm{E}, 44.283^{\circ} \mathrm{N}, \sim 640 \mathrm{~m}$; 181: Bambak Ridge, $\sim 40.667^{\circ} \mathrm{E}, 43.971^{\circ} \mathrm{N}, \sim 1400 \mathrm{~m}$; 182: Chernorech'e check point, $\sim 40.683^{\circ} \mathrm{E}, 43.933^{\circ} \mathrm{N}$, $\sim 836 \mathrm{~m}$; 183: Kirovskiy, $\sim 40.685^{\circ} \mathrm{E}, 43.945^{\circ} \mathrm{N}, \sim 833$ m; 184: Nikitino, $\sim 40.700^{\circ} \mathrm{E}, 43.963^{\circ} \mathrm{N}, \sim 793 \mathrm{~m} ; 185$ : Besleneevskaya, $\sim 40.704^{\circ} \mathrm{E}, 44.235^{\circ} \mathrm{N}, \sim 492 \mathrm{~m} ; 186$ : Tretya Rota check point, $\sim 40.717^{\circ} \mathrm{E}, 43.885^{\circ} \mathrm{N}, \sim 936 \mathrm{~m}$; 187: Psebay, $\sim 40.851^{\circ} \mathrm{E}, 44.163^{\circ} \mathrm{N}, \sim 630 \mathrm{~m}$; 188 : Agura waterfalls, $\sim 39.827^{\circ} \mathrm{E}, 43.559^{\circ} \mathrm{N}, \sim 215 \mathrm{~m}$.

North Ossetia-Alania Republic, Russia (1 locality) 189: Lesken, $\sim 43.769^{\circ} \mathrm{E}, 43.244^{\circ} \mathrm{N}, \sim 770 \mathrm{~m}$.

South Ossetia (12 localities)

190: Nyfsykau, $43.680^{\circ} \mathrm{E}, 42.258^{\circ} \mathrm{N}, 1010 \mathrm{~m}$; 191: Sinagur, $43.620^{\circ} \mathrm{E}, 42.392^{\circ} \mathrm{N}, 1010 \mathrm{~m}$; 192 : Sina- 
gur, $43.597^{\circ} \mathrm{E}, 42.402^{\circ} \mathrm{N}, 1050 \mathrm{~m} ; 193$ : Perevikokhita point, $43.641^{\circ} \mathrm{E}, 42.424^{\circ} \mathrm{N}, 1512 \mathrm{~m}$; 194: Nakatodari point, $43.654^{\circ} \mathrm{E}, 42.436^{\circ} \mathrm{N}, 2050 \mathrm{~m}$; 195: Kvaysa Mt., $43.650^{\circ} \mathrm{E}, 42.517^{\circ} \mathrm{N}, 1831 \mathrm{~m} ; 196$ : Dzau, $43.926^{\circ} \mathrm{E}$, $42.400^{\circ} \mathrm{N}, 1160 \mathrm{~m} ; 197$ : Kvemo-Khvtse, $43.954^{\circ} \mathrm{E}$, $42.413^{\circ} \mathrm{N}, \sim 1115 \mathrm{~m}$; 198: Gudusidon River, $43.962^{\circ} \mathrm{E}$, $42.411^{\circ} \mathrm{N}, 1134 \mathrm{~m}$; 199: Orbodzala Mt., $44.171^{\circ} \mathrm{E}$, $42.248^{\circ} \mathrm{N}, 1957 \mathrm{~m} ;$ 200: Atsritskheu, $44.224^{\circ} \mathrm{E}$, $42.297^{\circ} \mathrm{N}, 1325 \mathrm{~m}$; 201: South-Ossetia (= Liakhva) Nature Reserve, Malaya Liakhve River, $\sim 44.265^{\circ} \mathrm{E}$, $42.379^{\circ} \mathrm{N}, \sim 1550 \mathrm{~m}$.

Turkey (25 localities)

202: Zigana Pass, $\sim 39.373^{\circ} \mathrm{E}, 40.621^{\circ} \mathrm{N}, \sim 1340$ $\mathrm{m} ;$ 203: Akçaabat, $\sim 39.537^{\circ} \mathrm{E}, 40.930^{\circ} \mathrm{N}, 1060 \mathrm{~m}$; 204: Meryemana, $\sim 39.653^{\circ} \mathrm{E}, 40.700^{\circ} \mathrm{N}, 1000 \mathrm{~m} ; 205$ : Çaykara, $7 \mathrm{~km} \mathrm{~S}, \sim 40.274^{\circ} \mathrm{E}, 40.625^{\circ} \mathrm{N}, 800 \mathrm{~m} ; 206$ : Uzun Lake (=Uzungöl), $40.285^{\circ} \mathrm{E}, 40.622^{\circ} \mathrm{N}, 1100 \mathrm{~m}$;
207: İkizdere, $\sim 40.557^{\circ} \mathrm{E}, 40.772^{\circ} \mathrm{N}, 600 \mathrm{~m} ; 208:$ Teziha, $\sim 40.885^{\circ} \mathrm{E}, 41.175^{\circ} \mathrm{N}, 400 \mathrm{~m} ; 209$ : Çat, $\sim 40.935^{\circ} \mathrm{E}$, $40.860^{\circ} \mathrm{N}, 1200 \mathrm{~m} ; 210$ : Ülkü, $40.938^{\circ} \mathrm{E}, 40.975^{\circ} \mathrm{N}, 450$ m; 211: Meydanköy, 40.940 $\mathrm{E}, 40.980^{\circ} \mathrm{N}, 920 \mathrm{~m} ; 212$ : Şenyuva, $40.970^{\circ} \mathrm{E}, 40.990^{\circ} \mathrm{N}, \sim 415 \mathrm{~m}$; 213: Ardeşen, 8 $\mathrm{km} \mathrm{S}, \sim 40.987^{\circ} \mathrm{E}, 41.188^{\circ} \mathrm{N}, 50 \mathrm{~m} ; 214$ : Çamlihemsin, $\sim 41.005^{\circ} \mathrm{E}, 41.049^{\circ} \mathrm{N}, \sim 300 \mathrm{~m} ; 215$ : Duygulu, $41.040^{\circ} \mathrm{E}$, $41.110^{\circ} \mathrm{N}, \sim 486 \mathrm{~m} ; 216$ : Hoşdere, $41.040^{\circ} \mathrm{E}, 41.120^{\circ} \mathrm{N}$, $\sim 200 \mathrm{~m} ; 217$ : Cankurtaran pass, $\sim 41.505^{\circ} \mathrm{E}, 41.386^{\circ} \mathrm{N}$, 700 m; 218: Kafkasör, $41.774^{\circ} \mathrm{E}, 41.164^{\circ} \mathrm{N}, \sim 1750 \mathrm{~m}$; 219: Camili Biosphere Reserve, $\sim 41.896^{\circ} \mathrm{E}, 41.475^{\circ} \mathrm{N}$, $\sim 420 \mathrm{~m} ; 220$ : Kars, $20 \mathrm{~km} \mathrm{NW}, 43.107^{\circ} \mathrm{E}, 40.795^{\circ} \mathrm{N}$, $\sim 1875 \mathrm{~m} ; 221$ : Hidirnebi, $239.433^{\circ} \mathrm{E}, 40.954^{\circ} \mathrm{N}, 1400$ m; 222: Pazar, $\sim 40.884^{\circ} \mathrm{E}, 41.177^{\circ} \mathrm{N}, \sim 65 \mathrm{~m} ; 223: \mathrm{Zi}-$ kale, $\sim 41.004^{\circ} \mathrm{E}, 41.029^{\circ} \mathrm{N}, \sim 363 \mathrm{~m} ; 224$ : Ayder Yaylasi, $41.101^{\circ} \mathrm{E}, 40.954^{\circ} \mathrm{N}, \sim 1311 \mathrm{~m} ; 225$ : Uzun Lake, $2 \mathrm{~km} \mathrm{~N}, \sim 40.276^{\circ} \mathrm{E}, 40.635^{\circ} \mathrm{N}, \sim 1000 \mathrm{~m} ; 226$ : Çaykara, $40.317^{\circ} \mathrm{E}, 40.717^{\circ} \mathrm{N}, 450 \mathrm{~m}$.

\title{
РАСПРОСТРАНЕНИЕ И ПРИРОДООХРАННЫЙ СТАТУС КАВКАЗСКОЙ КРЕСТОВКИ PELODYTES CAUCASICUS (AMPHIBIA: ANURA)
}

\author{
С. Н. Литвинчук ${ }^{1}$, А. А. Кидов ${ }^{2}$ \\ ${ }^{1}$ Институт ичитологии РАН, Россия \\ e-mail: litvinchukspartak@yandex.ru \\ ${ }^{2}$ Российский государственный аграрный университет - МСХА имени К.А. Тимирязева, Россия

\begin{abstract}
Pelodytes caucasicus населяет Турцию, Грузию, Абхазию, Южную Осетию, Азербайджан и шесть регионов России (226 местонахождений). Вырубка лесов создает серьезную угрозу ее популяциям. Поэтому этот вид включен в Красные книги Грузии, Южной Осетии, Азербайджана, России. Среди прочих факторов, вызывающих сокращение популяций $P$. caucasicus, являются разрушение и загрязнение подходящих вододоемов, санитарная рубка леса, уничтожение подстилки, смертность на дорогах и уничтожение чужеродным видом Procyon lotor. Используя программу MaxEnt, мы разработали модель распространения вида, основанную на данных по климату, ландшафту и растительному покрову, чтобы оценить область потенциального распространения, экологические предпочтения и природоохранный статус P. caucasicus. Два параметра (количество осадков за год и сезонность осадков) имели наибольший процентный вклад в эту модель (52\% и $11 \%$ соответственно). Как правило, подходящие места обитания для вида располагались в областях распространения горных лесов с годовым количеством осадков от 513 до 2376 мм. Более сухие районы на севере и юге Кавказа являются границей распространения P. caucasicus.
\end{abstract}

Ключевые слова: MaxEnt, Pelodytidae, ГИС-моделирование, Кавказ 